Kazimierz Adamczyk

Uniwersytet Jagielloński

kazimierz.adamczyk@uj.edu.pl

\title{
„Czy świadek szuka zemsty?” Świadectwo, propaganda, dydaktyka w powieściach obozowych Danuty Brzosko-Mędryk
}

\author{
"Does the Witness Seek Revenge?" Testimony, Propaganda and Didacticism in the \\ Concentration Camp Novels of Danuta Brzosko-Mędryk
}

\begin{abstract}
The article discusses the now-forgotten lierary work of Danuta Brzosko-Mędryk (died 2015), an internee of KZ Lublin, KZ Ravensbrück and KZ Buchenwald, author of seven books, of which five are devoted to the experience of internment. The essay analyses the objectives of the books, especially in the context of the literature of testimony. It also describes the reception of Brzosko-Mędryk's work in the Communist Poland and today. Her book Niebo bez ptaków [A Sky Without Birds] was successful and the writer was summoned as a witness in trials against the Nazi German authorities of the death camp in Majdanek. Those trials, held in New York and Düsseldorf, became the subject of her other book, $C z y$ swiadek szuka zemsty? [Does the Witness Seek Revenge?]. All of Brzosko-Mędryk's novels were published in the Communist Poland, so they were subjected to the publishing policy of the state. The essay underlines the most important element of the writer's memories: giving testimony to the heroic attitudes of Polish women held in Nazi German concentration camps.
\end{abstract}

Keywords: Danuta Brzosko-Mędryk, concentration camp, women, testimony, didacticism, propaganda

Streszczenie: W artykule omówiona zostaje zapomniana dzisiaj literacką twórczość zmarłej w 2015 roku Danuty Brzosko-Mędryk, byłej więźniarki obozów KL Lublin, FKL Ravensbrück i KL Buchenvald, autorki siedmiu książek, z których pięć poświęcona jest doświadczeniu lagrowemu. Autor omawia dyrektywy lektury, zwłaszcza w kontekście zagadnień literatury świadectwa. Pisze również o recepcji jej twórczości w okresie PRL-u i współcześnie. Książka Niebo bez ptaków odniosła sukces, a Brzosko-Mędryk powoływana była na świadka w procesach przeciwko niemieckim władzom obozu na Majdanku. Procesy te, toczące się w Nowym Jorku i Düsseldorfie, uczyniła tematem książki Czy świadek szuka zemsty? Wszystkie jej utwory ukazały się w czasach PRL-u, podlegały więc polityce wydawniczej państwa. Autor szkicu wskazuje najważniejszy rys wspomnień Brzosko-Mędryk: dawanie świadectwa heroicznej postawie polskich kobiet więzionych w niemieckich obozach koncentracyjnych.

Słowa kluczowe: Danuta Brzosko-Mędryk, obóz koncentracyjny, kobiety, świadectwo, dydaktyzm, propaganda 
Siedziałam tak długo w towarzystwie międzynarodowym w obozie. Obserwowałam ludzi w sytuacjach takich, w jakich się ich normalnie nigdy nie widzi. Utwierdziłam tylko swoje dawne przekonanie, że nie istnieją cechy narodowe czy rasowe, żadne różnice. Kryminaliści wszystkich narodowości, to tylko kryminaliści. Ludzie uczciwi wszędzie jednakowi. W różnych systemach społecznych różne kwiatki kwitną. Przekonana jestem, że masy Polaków można wychować na cudownych hitlerowców, jak również, że z niektórych Niemców nigdy hitlerowców się nie zrobi.

(List Marii Rundo do Mieczysława Grydzewskiego z 26 lutego 1946 roku$^{1}$ )

Danuta Brzosko-Mędryk zmarła 15 września 2015 roku w wieku 94 lat. Była autorką siedmiu książek. Pięć z nich poświęconych jest tematyce lagrowej. Debiutowała w roku 1968, kiedy to Wydawnictwo Ministerstwa Obrony Narodowej opublikowało jej pamiętnik nadesłany na konkurs wspomnień więźniów obozu KL Lublin zatytułowany Niebo bezptaków. Autorka zdobyła wówczas drugie miejsce, lecz pierwszej nagrody nie przyznano. Istotny jest fakt, iż była to pierwsza ogłoszona drukiem relacja więźniarki. Wydawane wcześniej materiały wspomnieniowe wychodziły spod pióra mężczyzn. Losy kobiet uwięzionych w obozie koncentracyjnym na Majdanku były zatem prawie nieznane licznemu wówczas gronu czytelników autobiograficznych relacji wojennych.

Dwa lata później, w roku 1970, ukazała się opowieść o trzech kobietach-więźniarkach zatytułowana Matylda. Brzosko-Mędryk wraca w niej do losów kobiet znanych jej osobiście, które odgrywały ogromną rolę w kształtowania się postaw duchowego oporu więźniarek Majdanka. Przypomnijmy, iż po ewakuacji z lubelskiego obozu autorka więziona była także w Ravensbrück i Buchenwaldzie. Wyzwolenia doczekała się w Lipsku, w komandzie KL Buchenwald. Jej kolejna książka Czy świadek szuka zemsty? pojawiła się na półkach księgarskich w roku 1976. W swojej podstawowej warstwie fabularnej jest ona reporterskim sprawozdaniem z procesu Herminy Braunsteiner-Ryan, nadzorczyni SS z Majdanka. Opisany przez Brzosko-Mędryk proces toczył się przed sądem federalnym w Nowym Jorku, a pisarska zeznawała w nim jako świadek oskarżenia - na zaproszenie rządu Stanów Zjednoczonych. O wezwaniu na rozprawę zadecydowało to, że była autorką Nieba bez ptaków, co bardzo dobitnie poświadcza historyczną wiarygodność tego pamiętnika. Wyrokiem amerykańskiego sądu Herminę Braunsteiner-Ryan deportowano do Republiki Federalnej Niemiec, gdzie w Düsseldorfie odbył się trwający ponad pięć lat proces przeciwko szesnastu zbrodniarzom z Majdanka. Danuta Brzosko-

${ }^{1}$ List wysłany z Lund w Szwecji. Zob. T. Drewnowski, Niedyskrecje pocztowe, Warszawa 2001, s. 131. 
-Mędryk ponownie wystąpiła w sądzie jako świadek zbrodni. Wrażenia z tego procesu dołączyła jako drugą część do trzeciego już wydania książki $C z y$ świadek szuka zemsty?, które ukazało się w 1983 roku. Lata stanu wojennego w Polsce z pewnością nie sprzyjały czytelniczemu zainteresowaniu problematyką osądzenia niemieckich zbrodniarzy. Na nikły odzew procesu w Düsseldorfie ze strony oficjalnych polskich instytucji i rządowych mediów autorka wprost skarży się w uaktualnionej wersji swojej książki. Wymienione wyżej tytuły i wydania ukazały się nakładem wspomnianego Wydawnictwa Ministerstwa Obrony Narodowej.

Problematyce lagrowej poświęcona jest również kolejna książka Brzosko-Mędryk „Mury” w Ravensbrück, wydana w roku 1979 przez Młodzieżową Agencję Wydawniczą. Profil wydawnictwa w sposób widoczny wskazujena młodego czytelnika jako zamierzonego adresata książki, tym samym można mówić o dydaktycznym wymiarze tego świadectwa. Tematyka obozowa pojawia się także w książce Brzosko-Mędryk zatytułowanej Spirale życia (z roku 1972). Jest to próba zmierzenia się z literaturą fikcjonalną. Wydawcą tej pozycji ponownie była oficyna Ministerstwa Obrony Narodowej.

Poza wymienionymi tytułami zmarła dwa lata temu pisarka opublikowała jeszcze opowieść zatytułowaną Dziewczęta warszawskie oraz książkę Powiedz mojej córce. Ta pierwsza pozycja poświęcona została młodym polskim patriotkom zaangażowanym w rozmaity sposób w ruch oporu przeciwko niemieckiemu okupantowi w stolicy. Ostatnia z wymienionych opowiada o wojennych losach ojca pisarki. Cała literacka twórczość Danuty Brzosko-Mędryk koncentruje się wokół tematu polskich kobiet, przedstawiane są więc losy więźniarek i patriotek walczących z nazistowskim reżimem. Oczywiście w tle pisanych przez nią relacji pojawią się współwięźniarki innych narodowości oraz członkinie nadzoru nazistowskich niemieckich obozów.

Książki Brzosko-Mędryk jak dotąd lokowały się poza współczesnym horyzontem refleksji badawczej historyków literatury zajmujących się prozą lagrową, pomijane są także przez badaczki kobiecego doświadczenia lagru i tematyki Holocaustu, a przecież losom Żydów i Żydówek autorka poświęciła sporo uwagi. Przypomnijmy, iż KL Lublin był - podobnie jak KL Auschwitz-Birkenau - obozem zagłady. Gdyby nie internet, dość trudno byłoby dotrzeć do informacji o autorce i jej twórczości. Nazwiska Brzosko-Mędryk próżno bowiem szukać w przewodniku encyklopedycznym Literatura polska XX wie$k u$ czy w wielotomowym, tak zwanym złotym, słowniku biobibliograficznym Wspótcześni polscy pisarze i badacze literatury. Trudno też rozstrzygnać, dlaczego postać i twórczość pisarki nie trafiły do tych powszechnie cenionych kompendiów literackich. Przeoczenie nie należy do błahych, ponieważ Niebo bez ptaków z pewnością nie jest wspomnieniem banalnym.

Obecnie książki Brzosko-Mędryk nie są łatwo dostępne, mimo iż w czasach PRL-u miały po kilka wydań. Tylko sporadycznie odnajdziemy je w bibliotekach, zapewne ze względu na brak wznowień i lichy papier, na jakim były drukowane. Można na nie trafić na portalu Allegro, co świadczy o tym, 
iż były kiedyś kupowane i - czasem znajdują się w domowych biblioteczkach. Jednakże utwory Danuty Brzosko-Mędryk nie awansowały do kanonu wspomnieniowej literatury obozowej. Czy krytycy nie dostrzegli w jej tekstach walorów literackich, czy zbyt mało przerażający był tu opis niemieckich zbrodni i cierpienia ofiar? A przecież sam spór sądowy o wartość dowodową Nieba bez ptaków powinien zapewnić książce długi żywot. Warto w tym miejscu dopowiedzieć, iż obrońca Herminy Braunsteiner-Ryan, oskarżanej w Nowym Jorku i w Düsseldorfie o mord na więźniarkach Majdanka, chciał podważyć wagę tego świadectwa, wskazując niesłusznie na jej antysemicki wydźwięk. Dodajmy, że w zbiorowej publikacji Majdanek 19411944 zredagowanej przez Tadeusza Mencla relacja Danuty Brzosko-Mędryk przywoływana jest w charakterze źródła historycznego. Co zatem decyduje o zapomnieniu tej twórczości? Dlaczego książki Danuty Brzosko-Mędryk nie są dzisiaj wznawiane? Być może rolę tu odgrywają względy polityczne, takie jak współpraca autorki z propagandowymi wydawnictwami PRL-u.

Wspomnienia z Majdanka Brzosko-Mędryk napisała na konkurs ogłoszony w roku 1965. Bez badań archiwalnych trudno powiedzieć, z jakimi uwagami redakcyjnymi oraz cenzorskimi spotkała się jej relacja. Warto jednak przypomnieć, iż w latach 1967-1968 rozgrywała się tak zwana sprawa encyklopedystów, opisana między innymi przez Adama Bromberga na łamach paryskiej „Kultury”. Jego pamiętnik został literacko opracowany w Memorbuchu Henryka Grynberga ${ }^{2}$. Bromberg był dyrektorem Państwowego Wydawnictwa Naukowego od roku 1953, z funkcji usunięto go trzy lata przed wydarzeniami marcowymi. W serii trzech artykułów Sprawy (nie tylko) wydawnicze opisuje on historię wydania w PRL-u Matej encyklopedii powszechnej PWN i Wielkiej encyklopedii powszechnej $P W N^{\beta}$ - w okresie antysemickiej nagonki inicjowanej przez nacjonalistyczne skrzydło PZPR-u z generałem Mieczysławem Moczarem na czele. Ofiarą tych działań stało się między innymi kolegium redakcyjne przygotowywanej encyklopedii PWN. W wyniku czystki - jak podaje Bromberg - trzydziestu „encyklopedystów” zostało wyrzuconych z pracy. Rzecz dotyczyła oskarżenia redaktorów o umniejszanie martyrologii Polaków, proponowanego rozdzielenia terminów obóz koncentracyjny i obóz zagłady, a także informacji, iż ofiarami w obozach zagłady w 99 procentach byli Żydzi. Rozpoczęły się pomówienia o obrażanie byłych więźniów obozów koncentracyjnych, przemilczanie cierpień narodu polskiego, zaniżenie statystyki biologicznych strat. $\mathrm{Na}$ wiecach pojawiały się takie hasła, jak „Syjoniści fałszują historię”. Ostatecznie zadecydowano - pisze Grynberg - iż podział na obozy koncentracyjne i obozy zagłady jest fałszywy,

${ }^{2}$ H. Grynberg, Memorbuch, Warszawa 2000.

${ }^{3}$ A. Bromberg, Encyklopedyści (I), „Kultura” (Paryż) 1973, nr 7-8, s. 174-173; tenże, Encyklopedyści (II), „Kultura” (Paryż) 1973, nr 9, s. 123-128; tenże, Encyklopedyści (III), „Kultura” (Paryż) 1973, nr 10, s. 157-164. 
bowiem wszystkie obozy koncentracyjne w istocie uznać należy za obozy zagłady „stopniowej” lub „natychmiastowej”. Celem więc było - czytany dalej w Memorbuchu - „wyniszczenie narodów, głównie słowiańskich, a wśród nich przede wszystkim narodu polskiego i narodów ZSRR oraz Żydów”. Adam Bromberg zauważa, iż „sprawa "syjonistycznego spisku« w zespole encyklopedystów była drobnym, ale taktycznie znakomicie dobranym pretekstem do kampanii „patriotycznej” ${ }^{5}$ Mieczysława Moczara.

Okoliczności wydania Nieba bez ptaków muszą być dostrzeżone. Wystarczy powiedzieć, że w redakcyjnej nocie wstępu do książki nie pojawi się żadne ze słów: „Żyd”, „Żydówka”, „Żydzi”, „żydostwo”, chociaż to przedstawiciele tego narodu byli najliczniejszymi ofiarami Majdanka. Jako czytelnicy nie potrafimy rozstrzygnąć, w jakim stopniu otoczenie historyczne wpłynęło na kształt opublikowanych wspomnień Danuty Brzosko-Mędryk. Faktem jest, iż zdania wręcz powielające zaprezentowaną tu „partyjną" linię interpretacji zamierzeń Niemców wobec ludności polskiej, radzieckiej i żydowskiej odnajdziemy na kartach Nieba bez ptaków. Zwraca też uwagę odbiorcy relacja o wspólnym obchodzeniu przez Rosjanki, Białorusinki i Polki świąt Bożego Narodzenia oraz Wielkiej Nocy, a także o taktownym zachowaniu w tych dniach ateistycznych przecież komunistek rosyjskich. W książce bardzo mocno uwypuklony został solidaryzm więźniarek, wywodzących się z różnych orientacji politycznych: socjalistek, komunistek oraz „endeczek”. Czytelnik świadom kontekstu historycznego, w jakim opublikowana została książka, może odczuwać dyskomfort spowodowany rozpoznaniem w niej propagandowych klisz. Tyle tylko, że nie może on zakwestionować wiarygodności przedstawionego świadectwa. Niebo bez ptaków jest modelowym przykładem zawarcia z czytelnikiem paktu autobiograficznego wraz z jego zobowiązaniem mówienia prawdy. I tu pojawia się podstawowy kłopot w odbiorze literackiej twórczości Danuty Brzosko-Mędryk. Można bowiem rozpoznać, o czym za chwilę będzie mowa, kilka konkurencyjnych dyrektyw lektury.

Po pierwsze, bez wątpienia autorka pragnie zaświadczać, czyli przyjmuje nakaz powiedzenia prawdy o zbrodniach niemieckich, o cierpieniu ofiar obozów i duchowym oporze polskich więźniarek Majdanka. W Matyldzie jednoznacznie określi cel, jaki stawia swojemu pisarstwu: „przeżyłyśmy, by dać świadectwo prawdzie, przeżyłyśmy dzięki ogromnej woli przetrwania, wzajemnej pomocy i oporowi stawianemu Niemcom"6. Faktograficzną wartość Nieba bez ptaków podkreślają piszący o tej książce. Anna Wiśniewska na łamach „Zeszytów Majdanka” wprost stwierdziła, iż „W oparciu o jej uwagi [Brzosko-Mędryk - przyp. K.A.] można dokładnie odtworzyć życie ludzi skazanych

${ }^{4}$ H. Grynberg, dz. cyt., s. 262-264. Relacja Grynberga napisana została na podstawie zapisków Adama Bromberga.

5 A. Bromberg, Encyklopedyści (III), dz. cyt., s. 162.

${ }^{6}$ D. Brzosko-Mędryk, Matylda, Warszawa 1972, s. 82. 
na zamknięcie w obozie, proces konfrontacji i przystosowywania się do rzeczywistości obozowej”. W tym tekście pojawia się konkluzja, iż książka jest „ważkim źródłem do dziejów Majdanka”.

Po drugie, celem autorki jest dydaktyzm - realizowany poprzez informacje o niemieckich zbrodniach, ukazanie postaw patriotycznych, refleksje nad znaczeniem solidarności ludzkiej oraz rolą działalności kulturalno-oświatowej dla przetrwania nawet tak dramatycznego terroru. $\mathrm{Na}$ oczywisty wymiar dydaktyczny tego przekazu, pisząc o Matyldzie, wskazuje między innymi Elżbieta Rosiak ${ }^{8}$.

Po trzecie, widoczna jest, aczkolwiek w sposób śladowy, dyrektywa propagandowa. Takie założenie rozpoznamy we wspomnianej charakterystyce hitlerowskiej polityki, obrazie internacjonalistycznej współpracy więźniarek, wyeksponowaniu patriotycznej postawy młodych Polek. Zatem w tym aspekcie jej pamiętnik zbliża się do strategii perswazyjnej przyjętej w Kamieniach na szaniec Aleksandra Kamieńskiego. Z kolei w książkach relacjonujących proces Herminy Braunsteiner-Ryan odnajdziemy krytykę Zachodu i amerykańskiej agresji na Wietnam, jak również uwagi o bezkarności niemieckich zbrodniarzy wojennych. W tych dwóch ostatnich kwestiach poglądy Brzosko-Mędryk jak najbardziej wyrażają linię propagandową PRL-u, z tym jednak, że Amerykanie rzeczywiście dokonywali zbrodni w Wietnamie, a w ich kraju bezpieczne schronienie znalazło wielu nazistów.

Po czwarte, nieobce są autorce ambicje literackie, inaczej więc mówiąc, w omawianych utworach obowiązuje także dyrektywa artyzmu. Pisarka sięga po chwyt kontrapunktu, emfazę, schematy powieści sensacyjnej, elementy sztuki reportażu sądowego, dramaturgiczne ujęcie starcia protagonistów, zwroty do czytelnika i monolog wypowiedziany adresowany do portretowanej w utworze osoby. Recenzenci podkreślali zdolność kreślenia portretów współwięźniarek, obiektywizm i autentyzm relacji, zarzucają natomiast zbytnią egzaltację i przydługie opisy. Ta ostatnia opinia pióra Wiesława Pielechy odnosi się do książki Czy swiadek szuka zemsty??

Spójrzmy zatem, jak wymienione dyrektywy realizowane są w poszczególnych książkach Danuty Brzosko-Mędryk. Warto też zwrócić uwagę na strategię promocyjną widoczną we wstępach i w treści zdań zapisanych na skrzydełkach okładek. Niewątpliwie najważniejszą pozycją w dorobku Brzosko-Mędryk pozostaje, jak pisałem, Niebo bez ptaków. Na okładce tej pozycji przeczytamy, iż tego „pamiętnika się nie czyta”, lecz „ten pamiętnik się przeżywa”. W tej sekwencji znalazło się zdanie, że autorka poznała „prawie cały zbrodniczy system

7 A. Wiśniewska, Danuta Brzosko-Mędryk: „Niebo bez ptaków” (recenzja), „Zeszyty Majdanka” 1969, t. 4, s. 303.

${ }^{8}$ E. Rosiak, Danuta Brzosko-Mędryk: „Matylda” (recenzja), „Zeszyty Majdanka” 1972, t. 6, s. 218.

9 W. Pielecha, Danuta Brzosko-Mędryk: „Czy świadek szuka zemsty?”, „Zeszyty Majdanka” 1980, t. 10, s. 220. 
unicestwienia ludzi”. Przeczytamy również, iż jest to „książa optymistyczna: umacnia wiarę w człowieka, w zwycięstwo tego, co jest w nim najlepsze i najszlachetniejsze". Przyznajmy, iż współczesny czytelnik wychowany na prozie Tadeusza Borowskiego musi doznawać niepokoju, czytając te rekomendacje. Opinie pochodzące od wydawnictwa, eksponując wymiar dydaktyczny relacji, wydają się jednostronne, nadto upraszczające. A przecież Niebo bez ptaków, chociaż możemy świadectwo zaliczyć do narracji etosowej ${ }^{10}$, to jednak nie zawiera się ono całkowicie w tego rodzaju dyskursie. Poza takim ujęciem znajdują się opisane obszary przemocy, bezradności, okrucieństwa, zbrodni ludobójstwa, wobec których człowiek pozostaje całkowicie bezradny.

Autorka, aresztowana za działalność konspiracyjną, po niemal półrocznym uwięzieniu na Pawiaku zostaje przewieziona na Majdanek 17 stycznia 1943 roku, zaś obóz ten opuszcza w transporcie do Ravensbrück 18 kwietnia 1944 roku. Odwołując się do sporadycznie prowadzonego w tym czasie dziennika, stara się stworzyć sugestię zapisu powstałego na Majdanku. Zdaje sobie sprawę z wyjątkowości sytuacji, w jakiej znalazła się wraz z więźniarkami przysłanymi z Pawiaka. Znacząca część uwięzionych to kobiety wcześniej zaangażowane w działalność przeciwko okupantowi. Kobiecy obóz koncentracyjny na Majdanku znajdował się wówczas w fazie organizacji, a proces przebiegał od decyzji podjętej 1 października 1942 roku do utworzenia obozu samodzielnego 22 lutego 1943 roku. Ten organizacyjny chaos zaowocował zezwoleniem niemieckich władz obozu na samodzielny wybór funkcyjnych przez więźniarki. Zatem funkcje kapo i blokowych objęty kobiety cieszące się autorytetem uwięzionych, dlatego stanowiły one swoisty bufor między władzą obozu a häftlingami. Sytuacja była więc tu diametralnie inna niż w Auschwitz, gdzie funkcyjni więźniowie, wybierani spośród przestępców kryminalnych, tworzyli najczęściej pierwsze ogniwo terroru. Autorka Nieba bez ptaków ma świadomość tych radykalnych różnic. Pisze, iż kobiety przywiezione z Oświęcimia zachwycone były stosunkami koleżeńskimi w kobiecym obozie Majdanka, gdyż „tam blokowe i kapo to władza niemal absolutna, u nas takie same więźniarki”"

W bloku „pawiaczek” znajduje się początkowo około trzystu więźniarek, a później ich liczba dochodzi nawet do pięciuset. Wśród nich są doświadczone działaczki kulturalno-oświatowe związane z przedwojennymi partiami politycznymi. Sylwetkom tych kobiet poświęci Brzosko-Mędryk książkę Matylda. Zatem to raczej wyjątkowemu zbiegowi okoliczności (przede wszystkim nieprzygotowaniu KL Majdanka na przyjęcie kobiet) zawdzięczać należy powstanie w kobiecym obozie struktur samoorganizacji więźniarek, możliwości

${ }^{10}$ Pojęciem relacji etosowej w odniesieniu do patriotyczno-martyrologicznych obozowych narracji posłużyła się Barbara Czarnecka w referacie Etos romantyczny w kobiecych narracjach lagrowych wygłoszonym w 2016 roku na konferencji w Pobierowie „Romantyzm i polityka”. Książka pokonferencyjna ukaże się w roku 2018.

${ }_{11}$ D. Brzosko-Mędryk, Niebo bez ptaków, Warszawa 1980, s. 107-108. 
pracy kulturalnej, wykształcenia się form samopomocy i niemal rodzinnych więzów wśród osadzonych tu kobiet. Autorka pamiętnika podkreśla wspólne śpiewanie pieśni religijnych wzmacniających nadzieję przetrwania i nadających cierpieniu sens. Szczególną rolę przypisuje tak zwanemu Radiu Majdanek, czyli inscenizowanym audycjom w bloku „pawiaczek”. Brzosko-Mędryk była pierwszą spikerką tego „fałszywego radia”. Obraz społeczności więźniarek łatwo może być odebrany jako wyidealizowany, ale narysowany on jest mocną kreską i wsparty przekonującą socjologiczno-psychologiczną argumentacją. Według omawianej relacji ta bliska więź przetrwała także wtedy, gdy po likwidacji Majdanka jego wię́niarki znalazły się w innych obozach. Nie znaczy to bynajmniej, iż pisarka nie odnotowuje postaw odmiennych wśród „pawiaczek”, należą one jednak do wyjątków i spotykają się z potępieniem współwięźniarek.

Pamiętnik, według słów autorki, pisany był bezpośrednio po powrocie z obozu. Danuta Brzosko-Mędryk twierdzi, iż wysyłając go na konkurs po upływie lat trzydziestu, nie dokonywała w nim rewizji i przewartościowań: „Pragnę zachować świeżość i autentyzm ówczesnej małolaty” ${ }^{12}$. Założenie szczęśliwe, bowiem czytane wedle takich reguł Niebo bez ptaków staje się również rodzajem powieści inicjacyjnej. Do obozu trafia młodziutka dziewczyna, traktuje uwięzienie na Pawiaku, a potem pasiak z czerwoną literą „P” jako symbol pozbawienia wolności, swoisty medal za patriotyzm. Nie wie, co to jest puff, usiłuje zachować czystość, „nie zna jeszcze aktu oddania się mężczyźnie"13, przeraża ją swoboda seksualna. Kieruje się przykazaniem: „Gdziekolwiek się znajdę, zawsze będę godna miana Polski” ${ }^{14}$. Możemy powiedzieć, iż Niebo bez ptaków jest także opowieścią o godności Polek.

Bohaterka pamiętnika - młoda dziewczyna doznaje głodu, zimna, bicia, sprząta kwatery niemieckich oprawców, pracuje w komandzie opróżniającym ubikacje, jest zżerana przez wszy, jako przyuczona pielęgniarka zajmuje się zaropiałymi ciałami chorych, umyka śmierci, jest świadkiem kary słupka, chłosty kobiet, egzekucji. Obserwuje również nędzę męskich więźniów, umierających z głodu jeńców sowieckich, snujących się muzułmanów nazwanych w Majdanku gemlami, jest także świadkiem pokątnego mordu, sadyzmu, gazowania więźniów i masakry dokonanej w obozie 3 listopada 1943 roku, nazwanej przez Niemców „Erntefest” - dożynkami - kiedy to 18600 Żydów, żydowskich kobiet i dzieci zostaje zamordowanych w ciągu jednej doby ${ }^{15} . \mathrm{Z}$ pewnością horror cierpienia i śmierci zostaje przez nią

12 Tamże, s. 11.

13 Tamże, s. 129.

14 Tamże, s. 133.

15 Zob. Krwawa środa. 3 listopada 1943 roku w pamięci świadków, wybór wspomnień i oprac. K. Czuryszkiewicz, B. Siwek-Ciupak, Lublin 2013 oraz naukowe opracowanie Erntefest. Zapomniany epizod Zagtady 3-4 listopada 1943, red. W. Lenarczyk, D. Libionka, Lublin 2009. 
zaświadczony i doświadczony. Książka obfituje w zapisy imion i nazwisk, historii konkretnych więźniów. Widoczny jest tu zamiar ocalenia pamięci ofiar, a także pojawiają się świadectwa zbrodni oraz listy nazwisk morderców. Stąd późniejszy udział pamiętnika (jako materiału dowodowego) w procesach przeciwko katom z Majdanka.

Nie chcę dokonywać tutaj deszyfracji niewypowiedzianego wprost dystansu wobec żydowskich kobiet czy w ogóle - Żydów, co skądinąd łatwo możemy odnaleźć w wielu polskich relacjach obozowych. Brzosko-Mędryk wskazuje odrębność żydowskiego losu. Niemniej jednak, kiedy opisuje chaos, wybuchy płaczu i ekspresje rozpaczy pośród żydowskich kobiet przywiezionych do obozu, zaznacza wyższość Polek, które potrafiły się zdyscyplinować i zorganizować. Zamętu w żydowskim baraku nie mogły opanować niemieckie strażniczki. Porządek, poprzez perswazje i powagę zachowania, zaprowadziły dopiero dwie Polki, nazwane później „żydowskimi ciotkami”, gdyż to one właśnie dodawały otuchy zrozpaczonym więźniarkom żydowskim. Autorka jednym zdaniem zaznacza, że Żydówki wiedziały, iż czeka je śmierć, co być może tłumaczy ich zachowania. Wyróżnia się tutaj okrutna scena, kiedy to rozpoczyna się polowanie na żydowskie dzieci. Matki reagują rozmaicie, część wyrzeka się dzieci, oddając je oprawcom, gdyż zwycięża pragnienie życia, inne - w akcie rozpaczy - wskakują na przyczepy jadące do komór gazowych. Tymczasem polskie policjantki obozowe usiłują przeszkodzić Niemcom, ratują dzieci, chowają je w zakamarkach obozu, markują poszukiwania. Zostają po akcji ukarane chłostą. Zachowują się lepiej niż żydowskie kobiety ${ }^{16}$.

Dwojako odczytane może być zdanie inicjujące opis masakry z 3 listopada. Oto autorka obserwuje idący pod eskortą pochód. Pisze: „Ludzie idą”. Dopiero po kilku akapitach wyjaśnia się, iż do masowych grobów zmierzają Żydzi, rozpoznani przez nią po rysach twarzy i ubraniach. Czy mamy tu do czynienia tylko z celowym zabiegiem mającym podkreślić trudność obserwacji, czy echo ówczesnych reżimowych dyskusji dotyczących liczby polskich i żydowskich ofiar wojny? A może widoczny jest tu pogłos opowiadania Tadeusza Borowskiego Ludzie, którzy szli? W tym pogromie Niemcy oszczędzili 300 Żydówek, przeznaczając je do sortowania odzieży po rozstrzelanych. Systematycznie były one wybierane podczas selekcji do komór gazowych. Polki usiłują je przechować na rewirze w barakach, w końcu chwilowo ocalałe przewiezione zostają do Auschwitz i zagazowane. Wśród Polek od początku ukrywają się Żydówki udające Aryjki, ale jak pisze Brzosko: „staramy się o tym nie mówić, by zachować ich tajemnicę"17.

${ }^{16}$ Fakt godnego się zachowania polskich policjantek pojawia się i w innych relacjach, łagodniej oceniane są także postawy Żydówek. Zob. zwłaszcza relację Stefanii Bońskiej, Pót roku [w:] Jesteśmy świadkami. Wspomnienia bytych więźniów Majdanka, wybór i wstęp C. Rajca, E. Rosiak, A. Wiśniewska, Lublin 1969, s. 228-242.

${ }^{17}$ D. Brzosko-Mędryk, Niebo bez ptaków, dz. cyt., s. 85. 
Te obrazy Zagłady, śmierci i tortur stanowią kontrapunkt dla rzeczywiście zastanawiającej wizji wspólnoty polskich więźniarek umacniającej, jak głosi tekst na okładce książki, „wiarę w zwycięstwo człowieka, tego, co jest w nim najlepsze". Oczywiście nietaktem historyka i historyka literatury byłaby polemika z autorką. To przecież jej świadectwo. Powiedzieć możemy, iż punktem obserwacyjnym jest tu jednak specyficzna wspólnota jednego baraku „pawiaczek", a obrazy zagłady w tym wspomnieniu uwiarygodniają horror, którym był KL Majdanek.

Dwa lata po ukazaniu się Nieba bez ptaków Brzosko-Mędryk wraca do tematu Majdanka. Kolejna książka nosi tytuł Matylda. Składa się z trzech portretów kobiet - duchowych przewodniczek autorki, więźniarek i działaczek polityczno-oświatowych. Tytułowa Matylda to Mata Woliniewska, przedwojenna jeszcze działaczka PPS. Wanda - bohaterka kolejnego rozdziału to Wanda Ossowska, pielęgniarka, która doprowadza do powstania w kobiecym obozie na Majdanku szpitala i ratuje życie setkom kobiet, sama oczekując na wykonanie zasądzonego wyroku śmierci. Bohaterką ostatniej części książki jest natomiast Antonina Grygowa, właścicielka piekarni w Lublinie, organizująca żywnościową pomoc dla więźniów Majdanka i oflagów. Kreśląc portrety tych trzech działaczek, patriotek polskich, autorka nie stroni od patosu i egzaltacji, jakości spotęgowanych bezpośrednimi, pełnymi empatii zwrotami do przedstawianych bohaterek. W opowieści powracają znane fragmenty Nieba bez ptaków, najbardziej traumatyczne doświadczenia: selekcja dzieci i masakra Żydów z 3 listopada 1943 roku. W Matyldzie Majdanek zostaje określony zarazem jako obóz koncentracyjny i obóz zagłady.

22 września 1972 roku Danuta Brzosko-Mędryk stanęła jako świadek przed nowojorskim sądem w sprawie przeciwko Herminie Braunsteiner-Ryan oskarżonej o zbrodnie w Polsce i o kłamstwa w ankiecie imigracyjnej. Autorka Matyldy miała potwierdzić, iż oskarżona brała udział w selekcji dzieci do komór gazowych. Wyrok zapadł 24 kwietnia 1973 roku, a sąd apelacyjny potwierdził winę. Kilka miesięcy po pierwszej rozprawie, 6 sierpnia 1973 roku, strażniczka z Majdanka została deportowana do Republiki Federalnej Niemiec, gdzie czekał ją proces w Düsseldorfie. Pierwsze wydanie książki $C z y$ świadek szuka zemsty? z roku 1976 relacjonuje przebieg sprawy Herminy Braunsteiner przed amerykańskim sądem, zaś wydanie z roku 1983 rozszerzone zostało o relację z Düsseldorfu, gdzie pisarka ponownie zeznawała przed sądem jako świadek zbrodni popełnionych przez kilkunastu członków niemieckiej załogi KL Majdanek. W rozszerzonej wersji książki zauważymy „inwazję” historycznego i publicystycznego komentarza.

Podstawowy kłopot czytelnikowi i krytykowi sprawia gatunkowa kwalifikacja tej opowieści. Mamy tu bowiem do czynienia z autobiografią, świadectwem, elementami powieści sensacyjnej, wykładu historycznego, a także reportażu sądowego i podróżniczego. Bez trudu odnajdziemy też pewne wyznaczniki dyskursu propagandowego właściwego epoce. Zwraca również uwagę 
autorskie wyznanie dotyczące użyteczności fikcji w literaturze świadectwa. Nie chodzi mi tutaj o szczegółową analizę poetyki tej książki, ale komplikacje lektury - które sygnalizuję - oznaczają niepewność co do umowy, jaką autorka zawiera z czytelnikiem. Z jednej strony otrzymujemy zobowiązanie mówienia prawdy, poświadczone złożoną przed sądem przysięgą, z drugiej - sztafaż powieści sensacyjnej, czyli atmosferę niepewności, strachu, niezidentyfikowanych telefonów, sugestie o zetknięciu się z działalnością organizacji Odessa znanej choćby ze słynnej książki Fredericka Forsytha.

Proces Herminy Braunsteiner-Ryan opisywany jest jako pierwszy w Ameryce sąd nad zbrodniarzami nazistowskiej machiny. Autorka oskarża rząd amerykański o celową opieszałość w tropieniu zbrodniarzy wojennych, którzy znaleźli schronienie w USA. Nie oszczędza również Watykanu, pisząc o udziale dostojników państwa kościelnego w organizacji szlaku przerzutowego nazistów do Ameryki Południowej. Elementy marketingu decydowały zapewne o umieszczeniu na obwolucie fragmentów książki, eksponujących jej wymiar sensacyjny, a także psychologiczny, zapowiadający starcie ofiary i kata. Wydaje się, iż ten najbardziej ambitny wątek sygnalizowany tytułem nie znalazł tutaj wystarczającego artystycznego wyrazu. W rezultacie otrzymujemy, by użyć ciągle modnych - ale może już nie najmodniejszych terminów - powieść-hybrydę, kolaż czy melanż literatury świadectwa z literaturą sensacyjną, a przecież napisaną w najpoważniejszym zamiarze ukazania zbrodni, bezkarności oprawców, a także stworzenia apologii przyjaźni kobiet z baraku „majdaniaczek”.

To w ich imieniu i w imieniu Polski chce występować autorka, tu wyzna powody, dla których napisała Niebo bez ptaków. Mowa zatem będzie o chęci wzniesienia pomnika ofiarom Majdanka, złożenia im hołdu ${ }^{18}$, a w tej relacji znajdziemy następujący autokomentarz: „Moim celem było pokazanie na tle prawdy o obozie koncentracyjnym prawdy o godności polskiej dziewczyny i polskiej kobiety. O tym, jak myśmy tam walczyły o życie kobiet i dzieci”"19.

Godność polskiej dziewczyny to obok dokumentacji zbrodni kolejny wielki temat Brzosko-Mędryk. Obecny w każdej z jej książek. Na ową godność składają się patriotyzm, solidarność i czystość. Cechy te wyróżniają Polki na tle przedstawicielek innych narodów, szczególnie Żydówek. Stąd, próbując zdyskredytować autorkę jako świadka, obrońca Herminy Braunsteiner zapyta: „Świadek nie była dobrze ustosunkowana do Żydówek?”. Odpowiedź jest znamienna: „Jak i do innych, które zapomniały o godności, bez względu na narodowość" 20 .

Temat tak rozumianej godności Polek wysuwa się na plan pierwszy we wspomnianej Matyldzie oraz w przywołanych już „Murach” w Ravensbrück. Przedmiotem narracji są dzieje harcerskiej drużyny kobiecej zorganizowanej

18 Taż, Czy świadek szuka zemsty?, Warszawa 1976, s. 159.

19 Tamże, s. 177.

${ }^{20}$ D. Brzosko-Mędryk, Niebo bez ptaków, dz. cyt., s. 152. 
przez młode Polki w obozie w Ravensbrück. Jak czytamy w odredakcyjnej nocie, jest „to opowieść o męczeństwie, odwadze, przyjaźni, solidarności i woli przetrwania”. Byłe więźniarki dedykują książkę „młodzieży żyjącej w wolnej już, szczęśliwej ojczyźnie”, aby głębiej pojęła sens hymnu Związku Harcerstwa Polskiego, śpiewanego niegdyś przez druhny „Murów”... w obozie: „W Wzystko, co nasze Polsce oddamy/ w niej tylko życie, więc idziem żyć (...)"21. Inspiracja ze strony wydawcy polegała na przesłaniu autorce relacji byłych członkiń drużyny harcerskiej. Danuta Brzosko-Mędryk podjęła się zbudowania na ich podstawie spójnej literackiej opowieści. Książka opatrzona została mottem: „Wy, które zostaniecie/ pracujcie i za nas”. Powtórzmy, iż w całym tym przedsięwzięciu wydawniczym wybijają się na plan pierwszy motywy propagandowe. Po pierwsze, chodzi o dostarczenie młodzieży wzoru wychowawczego, po drugie, o zaanektowanie tej wojennej i przedwojennej przecież tradycji harcerstwa przez oficjalnie działający w PRL-u Związek Harcerstwa Polskiego, po trzecie, rzekłbym, iż mamy tu do czynienia z analogicznym zamiarem propagandowym, jakim była wojenna publikacja Kamieni na szaniec. Obie pozycje - oparte na faktach - uczyć miały patriotyzmu. W relacji Brzosko-Mędryk postawy dziewczyn z drużyny „Murów”... mają stać się wzorem dla młodych Polek z pokolenia nieznającego wojny i często w epoce Gierka - oskarżanego o hołdowanie zachodniemu modelowi konsumpcji. Dodajmy, iż bohaterki „Murów”... po wojnie włączyły się w działalność harcerstwa i wierne swojemu przesłaniu zostawały patronkami drużyn, brały udział w licznych spotkaniach z młodzieżą. Książka zrodzona z opracowania trzydziestu sześciu relacji opowiada o cierpieniu, śmierci i konieczności solidarnego działania, o podtrzymywaniu ducha oporu i ogromnej roli, jaką w tym zadaniu odgrywały lektury literackie, samokształcenie, prelekcje, pogadanki i akademie organizowane potajemnie w Ravensbrück. Danuta Brzosko-Mędryk napisała książkę adresowaną do młodego czytelnika, realizującą cele dydaktyczne, odwołującą się do polskiej tradycji romantycznej.

Jeśli miałbym najkrócej określić pisarstwo Danuty Brzosko-Mędryk, to powiedziałbym, iż jest ono świadectwem uwikłanym w dydaktyzm oraz ideologiczną propagandę. Niewątpliwie jej najlepszą książką jest Niebo bez ptaków. Tutaj konwencja autobiograficzna służy zaświadczeniu o zbrodni, a zatem okazuje się podstawową dyrektywą pisarską. Następnie utwory pisane są coraz wyraziściej z troską o zdobycie czytelnika (świadczy o tym choćby sięganie po elementy sensacyjnych fabuł) i zarazem - jego wychowanie. Utwór dydaktyczny ma wyraziście określonego adresata, propaganda nie istnieje bowiem bez zaprogramowanego odbiorcy, którego postawy tego rodzaju przekaz pragnie kształtować. Tak pomyślane dzieła literackie przynależą do literatury popularnej. Propagują obraz młodych idealistek, patriotek, więźniarek baraku „pawiaczek” na Majdanku i harcerek z Ravensbrück jako wzoru do naśladowania dla nowych generacji

${ }^{21}$ Taż, „Mury” w Ravensbrück, Warszawa 1979, s. 5. 
Polek i Polaków. Odwołują się one do wzorów polskiej kultury romantycznej. Dodajmy, iż mamy tu do czynienia z literaturą świadectwa stopniowo przekształcaną w literaturę popularną, czytankę - w szlachetnym, dydaktycznym znaczeniu tego pojęcia. Zderzmy ten opis świata $\mathrm{z}$ wiedzą, jaką z obozu wyniosła cytowana w motcie do niniejszego artykułu Maria Rundo.

Istnieje jeszcze inny wymiar tych opowieści, o którym pisałem, mianowicie uwikłanie w propagandę polityczną. Ten rodzaj dyskursu łatwo wskazać, przy czym propaganda polityczna nie zawsze oznacza kłamstwo i schlebianie władzy, chociaż dostrzeżemy i takie składniki wypowiedzi. Trudno jednak nie zgodzić się z Danutą Brzosko-Mędryk, kiedy krytykuje państwa Zachodu za brak energicznego ścigania i ukarania zbrodniarzy nazistowskich oraz Watykan za pomoc uciekającym z Europy SS-manom. Lata publikacji jej książek, to też okres sporu o polską i żydowską martyrologię, o ofiary obozów koncentracyjnych i obozów zagłady. Dostrzeżemy jednak ewolucję stosunku autorki do wymienionych kwestii. Dojrzałość sądu wiąże się z jej z uczestnictwem w życiu publicznym, jak również z udziałem w procesach w Nowym Jorku i Düsseldorfie. Przypomnijmy po raz kolejny, iż wydawnictwa, w których ukazywały się książki Brzosko-Mędryk, były oficynami o wyránie widocznej linii politycznej. Niemniej jednak należy się powstrzymać przed ryzykownymi opiniami, przed sądami zanadto jednostronnymi. Z pewnością dopiero, jeśli taki ślad istnieje, analiza dokumentacji wydawniczej, czyli zapisanych sugestii redakcyjnych czy cenzorskich ingerencji, mogłaby nam wyjaśnić, do jakiego stopnia autorka uległa politycznym naciskom oraz sugestiom wydawców.

\section{Bibliografia}

Abramowicz Z., Tak byto, Lublin 1962.

Aby swiat się dowiedziat... Nielegalne dokumenty z obozu Ravensbrück, oprac. red. K. Oleksy, I. Polska, Oświęcim 1980.

Bromberg A., Encyklopedyści (I), „Kultura” (Paryż) 1973, nr 7-8.

Bromberg A., Encyklopedyści (II), „Kultura” (Paryż) 1973, nr 9.

Bromberg A., Encyklopedyści (III), „Kultura” (Paryż) 1973, nr 10.

Brzosko-Mędryk D., Czy świadek szuka zemsty?. Warszawa 1976.

Brzosko-Mędryk D., Matylda, Warszawa 1972.

Brzosko-Mędryk D., „Mury” w Ravensbrück, Warszawa 1979.

Brzosko-Mędryk D., Niebo bez ptaków, Warszawa 1980.

Drewnowski T., Niedyskrecje pocztowe, Warszawa 2001.

Erntefest. Zapomniany epizod Zagtady 3-4 listopada 1943, red., oprac. W. Lenarczyk, D. Libionka, Lublin 2009.

Grynberg H., Memorbuch, Warszawa 2000.

Jesteśmy świadkami. Wspomnienia bytych więźniów Majdanka, wybór i wstęp C. Rajca, E. Rosiak, A. Wiśniewska, Lublin 1969. 
Krwawa środa. 3 listopada 1943 roku w pamięci świadków, wybór wspomnień i oprac. K. Czuryszkiewicz, B. Siwek-Ciupak, Lublin 2013.

Morawiec A., Literatura $w$ lagrze, lager $w$ literaturze. Fakt, temat, metafora, Łódź 2009.

Mówia świadkowie Ravensbrück, wybór, wstęp, oprac. E.S. Kruszewski, Kopenhaga 2001.

Pielecha W., Danuta Brzosko-Mędryk: „Czy świadek szuka zemsty?” [recenzja], „Zeszyty Majdanka” 1980, t. 10.

Rosiak E., Danuta Brzosko-Mędryk: „Matylda” [recenzja], „Zeszyty Majdanka” 1972, t. 6.

Serca niezagaste. Wspomnienia więźniarek z Ravensbrük, wybór, oprac. A. Gierczak, wstęp J. Zaborowski, Warszawa 1975.

Sterkowicz S., Kobiecy obóz koncentracyjny Ravensbrück, Włocławek 2006.

Wiśniewska A., Danuta Brzosko-Mędryk: „Niebo bez ptaków” [recenzja], „Zeszyty Majdanka" 1969, t. 4.

Zwyciężyty wartości. Wspomnienia z Ravensbrück, oprac. U. Wińska, Gdańsk 1985. 